\title{
Global surveillance of emerging diseases: the ProMED-mail perspective
}

\author{
Vigilância global de doenças emergentes: \\ a perspectiva da ProMED-mail
}

John P. Woodall 1,2

\footnotetext{
1 Policy Committee, ProMED-mail International Society for Infectious Diseases, 181 Longwood Avenue, Boston, Massachusetts, USA 2 Núcleo de Investigação de Doenças Infecciosas Emergentes, Departamento de Bioquímica Médica, Instituto de Ciências Biomédicas, Centro de Ciências da Saúde, Universidade Federal do Rio de Janeiro. Cidade Universitária. Rio de Janeiro, $R J$ 21941-590, Brasil.
}

\begin{abstract}
The Internet is changing the way global disease surveillance is conducted. Countries and international organizations are increasingly placing their outbreak reports on the Internet, which speeds up distribution and therefore prevention and control. The World Health Organization (WHO) has recognized the value of nongovernmental organizations and the media in reporting outbreaks, which it then attempts to verify through its country offices. However, WHO and other official sources are constrained in their reporting by the need for bureaucratic clearance. ProMED-mail <www.promedmail.org> has no such constraints, and posts outbreak reports 7 days a week. It is moderated by infectious disease specialists who add relevant comments. Thus, ProMED-mail complements official sources and provides early warning of outbreaks. Its network is more than 20,000 people in over 150 countries, who place their computers and time at the network's disposal and report on outbreaks of which they have knowledge. Regions and countries could benefit from adopting the ProMED-mail approach to complement their own disease surveillance systems.
\end{abstract}

Key words Communicable Diseases; Disease Outbreaks; Epidemiological Surveillance; Internet; Prevention and Control

Resumo A Internet está mudando a condução da vigilância global de doenças. Cada vez mais, os países e as organizações internacionais estão divulgando seus informes na Internet, o que acelera não apenas a distribuição desta informação, como também, consequentemente, a prevenção e controle das doenças. A Organização Mundial da Saúde (OMS) já reconheceu a importância das ONGs e da imprensa na notificação de surtos, que procura verificar posteriormente através de suas agências locais. Entretanto, a OMS e outras fontes oficiais sofrem restrições em seus relatórios pela obrigatoriedade da autorização burocrática, além de só publicarem informes nos dias úteis. A ProMED-mail <www.promedmail.org> não está sujeita a tais restrições. A rede é moderada por especialistas em doenças infecciosas, que acrescentam comentários relevantes. Assim, a ProMED-mail complementa as fontes oficiais e divulga alertas precoces relativos a surtos. Em mais de 150 países, a rede inclui mais de 20.000 profissionais, que colocam seus computadores e tempo à disposição da rede e notificam os surtos dos quais têm conhecimento. Regiões e países poderiam beneficiar-se da adoção do sistema ProMED-mail para complementar seus próprios sistemas de vigilância.

Palavras-chave Doenças Transmissíveis; Surtos de Doenças; Vigilância Epidemiológica; Internet; Prevenção e Controle 
Historically, the global surveillance of emerging diseases has involved collecting information about the who, when, where, and why of disease outbreaks and sending it up the chain of command to a level in the government where action could be taken for prevention and control. Global surveillance is, of course, the sum of national surveillance by many countries. Historically, they have accomplished this by publishing weekly or monthly reports and sending them out by mail. Apart from the lag between receiving reports and publication, in some developing countries it may take weeks for the mail to reach remote areas, let alone neighboring states, drastically diluting the usefulness of the information.

The Internet has begun to change this. Many disease-specific lists and newsgroups have sprung up on the Internet, discussing everything from hepatitis, leishmaniasis, and Lyme disease to onchocerciasis and its vector. FSNet, covering food safety, AgNet, and Animal Net are run out of the University of Guelph, Canada, and BSE-list out of the UK. The (UK) Hospital Infection Society operates his-l, and the (US) Association for Professionals in Infection Control and Epidemiology, Inc. runs APIC-l, both lists discussing hospital infections worldwide. The United Mission to Nepal operates tb.net, a discussion list on tuberculosis. There is a Malaria-list, and numerous Internet fora on HIV/AIDS, including ProCAARE < procaare@usa.healthnet.org >.

During the outbreak of enterovirus encephalomyocarditis in children in Sarawak in 1997, the government of Malaysia put up a website with daily updates of the number of new cases and deaths. It did the same for the Nipah virus epidemic in pigs and pig farmers in 1999. Similarly, the government of Hong Kong had a web page with daily epidemiological updates during the outbreak of "chicken flu" in 1997-98. Yet too many countries still adhere to reporting once a week or month on the Internet, which does not take full advantage of the immediacy the Internet offers.

\section{Regional reports}

Regional reports feed into global surveillance. The PAHO Epidemiological Report is a quarterly that does not carry routine outbreak statistics <http://www.paho.org/english/sha/ beindexe.htm>. The Pan American Foot \& Mouth Disease Center, which also reports equine encephalitis (zoonoses that can cause serious disease in humans) throughout the Americas, is at $<$ www.panaftosa.org.br $>$, but its last report on the Internet is for July 1999. Saninet is a regional information service on Agricultural Health coordinated by the Instituto Interamericano de Cooperacion para la Agricultura (IICA), through the Centro Regional Andino (CReA), and can be found at <www.iicasaninet. net>. It carries outbreak reports of interest to Latin America, including many re-posted from ProMED-mail (see below).

Eurosurveillance Weekly and Monthly at <http://www.eurosurv.org/> publish outbreak reports of regional interest, including importations from outside Europe (Table 1). Europe also has the following more or less restricted networks: European Center for the Epidemiological Monitoring of AIDS, the Euro-TB Program, European Working Group on Legionella Infections (EWGLI), European Influenza Surveillance System, and European Antimicrobial Resistance Surveillance System; Salm-Net, dealing with Salmonella disease, and Enter-Net, covering enteric diseases. Ideally, global surveillance should be keeping track of all of these reports.

\section{WHO's global surveillance}

For many decades the World Health Organization has required all signatories to the International Health Regulations (IHR) - which comprise nearly all the countries of the world - to report by telex, within 24 hours, every suspect case of cholera, plague, smallpox, and yellow fever, to be followed as soon as possible by confirmation. Unfortunately, countries have taken this obligation less and less seriously over the years, to the point where several countries refuse to admit they have cholera, while others, including the USA, delay reporting for long periods (Smallpox, having been eradicated, is no longer notifiable).

WHO has a website at <http://www.who. int/emc/surveill/index.html > with a page on Surveillance (WHO, 2000a). Regarding Global/ regional epidemiological surveillance: epidemic intelligence it says:

"To improve international preparedness for epidemic response, it is essential to actively collect information on ongoing outbreaks or rumors of outbreaks worldwide. This information is then rapidly verified and shared with the public health community. If the outbreak is confirmed, it is reported on this web site, in Disease Outbreak News and in the Weekly Epidemiological Record [WER]."

Regarding global surveillance networks, the website says:

“CSR [WHO's Communicable Disease Surveillance and Response] participates in world- 
wide surveillance activities and seeks to strengthen the global surveillance and control of communicable diseases. Existing surveillance networks include:

The 142 WHO country offices and 6 regional offices of $W H O$

Over 200 WHO Collaborating Centers

Over 60 HIV sentinel surveillance sites

190 UNAIDS country sites

World Bank resident missions."

Under global/regional laboratory surveillance: disease-specific global laboratory networks, are listed:

"110 National Influenza Centers in 83 countries and 4 WHO Collaborating Centers for Virus Reference and Research form FluNet, linking the global network of centers electronically and allowing each authorized center to enter data remotely every week and obtain full access to real-time epidemiological and virological information;

RABNET is a databank accessible via the Internet for data entry by national rabies reference laboratories/sites;

Over 50 antimicrobial resistance monitoring national reference laboratories can have access to Antimicrobial Resistance Information Bank (AR InfoBank) which provides quality information about drug resistance and resistance surveillance networks;

Networks of laboratories working on viral hemorrhagic fever, Creutzfeldt-Jakob disease, leishmaniasis, and African trypanosomiasis."

WHO also receives the output of GPHIN (Global Public Health Intelligence Network), a sophisticated restricted access system set up by Health Canada to systematically search current media sources on the Internet for health events.

Information on confirmed outbreaks is also available on WHO Outbreak News pages at http://www.who.int/emc/outbreak_news/index.html or by e-mail at majordomo@who.int (type <subscribe wer-reh> to receive regular updates by e-mail);

Weekly Epidemiological Record (WER) at http://www.who.int/wer/;

Global Cholera update at http://www.who. int/emc/diseases/cholera/index.html;

Special Influenza update at http://www. who.int/emc/diseases/flu/index.html;

Global Meningococcal Disease update at http://www.who.int/emc/diseases/meningitis/ 1999meningtable.html.

WHO's WER for 7 January 2000 has an article entitled "An integrated approach to communicable disease surveillance" (WHO, 2000b:1), which includes the following statement:
Table 1

Outbreaks reported by countries to WHO,

January-February 2000.

\begin{tabular}{|c|c|}
\hline WHO/IHR diseases & \\
\hline Cholera & $\begin{array}{l}\text { Benin } \\
\text { Burundi } \\
\text { Comoros } \\
\text { DR Congo } \\
\text { Ghana } \\
\text { Guatemala } \\
\text { India } \\
\text { Kenya } \\
\text { Madagascar } \\
\text { Malawi } \\
\text { Mozambique } \\
\text { Niger } \\
\text { Tanzania } \\
\text { Togo } \\
\text { Uganda } \\
\text { Zambia } \\
\text { Zimbabwe }\end{array}$ \\
\hline Plague & Madagascar, USA \\
\hline Yellow fever & $\begin{array}{l}\text { Bolivia } \\
\text { Brazil } \\
\text { Ecuador } \\
\text { Netherlands (imported) }\end{array}$ \\
\hline \multicolumn{2}{|l|}{ Other outbreaks } \\
\hline Dysentery & $\begin{array}{l}\text { Lesotho } \\
\text { Sierra Leone }\end{array}$ \\
\hline $\begin{array}{l}\text { Influenza } \\
\text { Lassa fever, imported }\end{array}$ & $\begin{array}{l}\text { Worldwide } \\
\text { Germany }\end{array}$ \\
\hline Listeriosis & France \\
\hline Marburg & DR Congo \\
\hline $\begin{array}{l}\text { Meningococcal } \\
\text { disease }\end{array}$ & $\begin{array}{l}\text { Central African Republic } \\
\text { Hungary }\end{array}$ \\
\hline $\begin{array}{l}\text { Poliovirus, wild, } \\
\text { imported }\end{array}$ & China \\
\hline Salmonella enteritidis & Denmark \\
\hline
\end{tabular}

Sources: WHO Weekly Epidemiological Record http://www.who.int/wer/75_1_26.html WHO Outbreak News

http://www.who.int/emc/outbreak_news/n2000/ index.html

"In the area of epidemic surveillance and response, public health authorities should give more attention to information from sources other than the public health sector, including NGOs and the media [emphasis added]. The capacity of public health authorities to rapidly respond to outbreak-related information from any source is essential for the efficiency and credibility of the entire surveillance effort." 
This last statement, coupled with the one above about collecting rumors of outbreaks for confirmation, signifies a sea change in WHO's approach to disease surveillance, from passive receiving of data to active searching. Reports picked up by WHO from the media and other unofficial sources are now sent to the WHO representative's office in the country concerned with a request for follow-up.

\section{ProMED-mail's global early warning}

In 1994 ProMED-mail was formed as an initiative of the Federation of American Scientists (FAS), with technical support from SatelLife of Boston, Massachusetts, USA. Its mission is to provide early warning, 7 days a week yearround, of outbreaks of emerging infectious diseases and episodes of acute toxicity, and the spread of antibiotic and disease vector resistance, worldwide, free of charge by e-mail. It is moderated by infectious diseases specialists to maintain a high level of scientific credibility (Mitchell, 1997; Woodall, 1997). As of November 2000, ProMED-mail had:

- 21,000 individual and institutional subscribers in 150 countries;

- 15,000 visits per month to its website $<$ www:promedmail.org>;

- WHO, CDC (Centers for Disease Control and Prevention), many ministries of health and universities subscribed.

There are almost 500 subscribers from CDC, which suggests that they find ProMED-mail reports well worth receiving. The 21,000 subscribers, one-third of them located outside the USA, use their own computers to receive and redistribute the reports they receive, all at no cost in equipment or personnel time to ProMEDmail, and each one is a potential provider of outbreak reports, sending them on to ProMEDmail. No other system can match that number of computers and unpaid contributors.

ProMED-mail seeks to complement, not compete with, other systems of global and national infectious disease surveillance. It concentrates on rapid reporting of outbreaks rather than detailed epidemiological surveillance. It seeks to alert all those with an interest in preventing and controlling outbreaks of newly emerging infections, and this includes the informed general public, which forms probably half of its subscribers. In 1999 ProMEDmail left FAS and SatelLife to become a program of the International Society for Infectious Diseases, in collaboration with the Harvard School of Public Health and the Oracle Corporation.

\section{Timeliness of reporting}

Any delay in publicly reporting details of new outbreaks translates into a delay in implementing prevention and control measures. For example, a case of yellow fever in an unvaccinated tourist, returning from Brazil to die in Switzerland in April 1996, was not officially reported by Switzerland to WHO until late July. It is possible that during that interval, in the absence of an alert to physicians and the traveling public, other tourists went to Brazil without bothering to get vaccinated (Brazilian authorities recommend vaccination, but do not require it as a condition of entry). It is conceivable that reporting before the end of July could have prevented the death from yellow fever in August of an American tourist who traveled to the same part of Brazil without being vaccinated. In subsequent years there have been several more cases of unvaccinated tourists succumbing to yellow fever after visits to South America and Africa, the most recent confirmed case being that of an American tourist in Venezuela, who died back in the USA on 4 October 1999, but was only notified by Venezuela to WHO on 23 November 1999.

While notification to WHO was delayed, in some cases a news report was picked up by ProMED-mail and disseminated widely over the Internet much earlier, because ProMED-mail does not have to wait for official clearance before posting a report. The April 1996 case was reported by ProMED-mail on 1 July, 3 weeks before the official report. In 1999, ProMED-mail reported the following yellow fever outbreaks before WHO received authorization to publish them: Brazil, 2 days before; Germany (imported from the Ivory Coast), 5 days before; Peru, 9 days before.

Similar time differences were seen with the other notifiable diseases, cholera, and plague.

On Sunday, 4 April 1999, ProMED-mail received and posted, direct from the Pasteur Institute, Madagascar, the report of the first cases of cholera ever reported from that country. WHO put this on its OVL (see below) three days later, acknowledging ProMED-mail as a source. In 1999 ProMED-mail was able to report cholera outbreaks in 11 countries 3 days to 8 weeks (in the case of cholera in Peru) before WHO was able to, because WHO had to wait for country clearance. ProMED-mail also reported plague outbreaks in 8 countries 11 days to 4 weeks (in the case of plague in Colorado, USA) before WHO could, for the same reason. ProMED-mail even reported several times before CNN (Table 2). Note that in all cases the ProMED-mail report was subsequently officially confirmed. 
Outbreaks reported by ProMED-mail,

January-February 2000.

\begin{tabular}{ll}
\hline WHO/IHR diseases & \\
\hline Cholera & Burundi \\
& Comoros \\
& DR Congo \\
& El Salvador \\
& India \\
& Kenya \\
& Lesotho \\
& Madagascar \\
& Malawi \\
& Nigeria \\
& Peru \\
& Philippines \\
& Somalia \\
& Tanzania \\
& Uganda \\
& Zambia \\
& Zimbabwe \\
& \\
Plague & USA \\
& Bolivia \\
& Brazil \\
& Netherlands (imported) \\
\end{tabular}

Other outbreaks

\begin{tabular}{|c|c|}
\hline $\begin{array}{l}\text { Campylobacte } \\
\text { food poisoning }\end{array}$ & New Zealand \\
\hline $\begin{array}{l}\text { Crimean-Congo } \\
\text { hemorrhagic fever }\end{array}$ & $\begin{array}{l}\text { South Africa } \\
\text { United Arab Emirates }\end{array}$ \\
\hline Dengue & $\begin{array}{l}\text { Argentina } \\
\text { Brazil } \\
\text { Paraguay } \\
\text { Venezuela }\end{array}$ \\
\hline Diphtheria & India \\
\hline Dysentery & $\begin{array}{l}\text { India } \\
\text { Kenya } \\
\text { Sierra Leone } \\
\text { Indonesia } \\
\text { Russia } \\
\text { USA }\end{array}$ \\
\hline $\begin{array}{l}\text { Enterovirus, } \\
\text { infant deaths }\end{array}$ & Israel \\
\hline Febrile illness & Fed. States of Micronesia \\
\hline $\begin{array}{l}\text { Hantavirus pulmonary } \\
\text { syndrome }\end{array}$ & Argentina, Panama \\
\hline $\begin{array}{l}\text { Hemorrhagic fever, } \\
\text { renal syndrome }\end{array}$ & Russia \\
\hline Influenza A H3N2 & World roundup \\
\hline
\end{tabular}

(continued)

\begin{tabular}{|c|c|}
\hline Lassa fever, imported & Germany ex W. Africa \\
\hline Listeriosis & France \\
\hline Malaria & $\begin{array}{l}\text { Indonesia } \\
\text { Malaysia } \\
\text { Mexico } \\
\text { Taiwan ex Burma, } \\
\text { imported }\end{array}$ \\
\hline $\begin{array}{l}\text { Marburg hemorrhagic } \\
\text { fever }\end{array}$ & Congo, DR \\
\hline Meningitis, viral? & Greece \\
\hline $\begin{array}{l}\text { Meningitis, } \\
\text { meningococcal }\end{array}$ & Hungary, UK \\
\hline Nipah virus & Malaysia \\
\hline Poliomyelitis & China: alert \\
\hline Puumala virus infections & Finland \\
\hline Rabies & Nepal, South Africa \\
\hline Ross River/Barmah virus & Australia \\
\hline Salmonella, pet treats & Canada: recall \\
\hline $\begin{array}{l}\text { Salmonella typhimurium } \\
\text { DT104, ham }\end{array}$ & Ireland: recall \\
\hline Shigella, bean/salsa dip & USA: recall \\
\hline Trichinellosis, imported & UK ex Serbia \\
\hline Typhoid fever & India \\
\hline
\end{tabular}

This pattern was repeated for outbreaks of other diseases. WHO has an unofficial weekly e-mail list called the OVL (Outbreak Verification List) which has a circulation restricted to Ministries of Health and WHO Collaborating Centers, and which carries unconfirmed reports. But in 23 outbreaks in 1999 the OVL posting followed ProMED-mail reports (compared with 5 outbreaks in which it preceded ProMED-mail), all due to delays in countries reporting to WHO. In the case of a trichinellosis outbreak in Chile in October 1999, and an outbreak of undiagnosed disease in Pakistan in March 2000 - and a number of other outbreaks - WHO credited ProMED-mail as the source of its (unofficial) report. Part of the difference is due to the fact that WHO posts outbreak reports only on weekdays, compared to 7 days a week year-round for ProMED-mail. 


\section{Accuracy}

Besides timeliness, effective global surveillance requires accuracy, comprehensiveness, and a user-friendly format. WHO publishes its errata at the back of its Weekly Epidemiological Record one week later; ProMED-mail posts corrections prominently labeled at the same level as all other items, and so errors are highly visible and more rapidly corrected. In most cases, the error was due to the reporting source; for example, a newspaper report of September 1999 that cows in New York state had been infected with West Nile virus was due to a typographical error by the newspaper for "crows".

In October 1999 Iowa State University reported that a juvenile captive bear with extensive human contact had died and tested positive to rabies, leading to a massive search to identify and immunize contacts. Further tests failed to confirm the initial finding, and ProMEDmail posted a correction.

In December 1999, a ProMED-mail correspondent reported that, according to a travel website, due to a measles emergency in Bolivia that country was requiring measles vaccination of entering adult travelers. ProMED-mail posted that, then received and posted an official denial from Bolivia.

In February 2000 the Pennsylvania, USA, Department of Health reported the finding of falciparum malaria in a traveler returning from a supposedly malaria-free resort in Cancun, Mexico. CDC was unable to confirm this, and ProMED-mail immediately posted the correction.

In March 2000 a Spanish news agency reported, due to a confusion in the name of the location, that hemorrhagic fever cases were occurring in Uganda. WHO sent a correction to ProMED-mail which was posted immediately. Altogether, ProMED-mail retracted 15 of the 351 outbreak reports posted during the 7 month period, but 6 of those were official reports that were subsequently retracted officially. The remaining 9 were incorrect reports from contributors and the media, giving an error rate of $9 / 351=2.6$ percent.

\section{Comprehensiveness}

Detailed statistics are a requirement for epidemiological surveillance, the aim being to obtain a complete count of cases, broken down by age, sex, and other categories useful for epidemiological analysis. Some national surveillance systems attempt to do this; global systems do not, since the data burden is too great. The WHO and ProMED-mail systems limit themselves to reporting new outbreaks, with occasional updates. Table 3 shows the number of outbreaks reported by WHO on its Outbreak Page, WER, and public e-mail list during January and February 2000, Table 4 the larger number reported on ProMED-mail's e-mail list and website.

Note from the Tables the way the two systems complement each other. WHO reported cholera from 3 countries (Ghana, Guatemala, and Togo) from which ProMED-mail had no reports, while the latter posted from 3 other

Table 3

Outbreaks reported by Eurosurveillance Weekly, January-February 2000.

WHO/IHR diseases

None

Other outbreaks

Botulism, wound

Switzerland

Creutzfeldt-Jakob variant disease

Gastroenteritis, United Kingdom apparent viral, after eating Scottish oysters Lassa fever in a German student returning from Ghana and Ivory Coast Listeriosis linked to consumption of rillettes

Malaria imported Spain from Dominican Republic Canada from Mexico

Measles Netherlands: update Orthodox Jewish community Republic of Ireland

Meningococcal Scotland, increase infections

Rotavirus, unusual Netherlands (G9P6), neonatal ward

Salmonella rubislaw
infection, fatal neonatal,
in household with
pet reptile
Trichinellosis $\quad$ England

Source: http://www.eurosurv.org/update/ 
countries (El Salvador, Lesotho, and Peru) from which WHO received no official notification of cholera during the same period. Also, although WHO can report imported cases of the notifiable diseases, it cannot divulge the name of the country from which they are imported unless the latter gives official permission. But ProMED-mail seeks out that information from the importing country, and does not need to obtain official permission from the country of origin before posting.

This information is useful to public health officials around the world, who need to know which countries have not reported cholera, but are exporting it. Cholera endemic countries which do not routinely report diarrheal disease cases to WHO as cholera are Bangladesh, Egypt, Indonesia, Pakistan, Philippines, and Thailand. However, WHO was able to report that the fatal yellow fever case in Germany in August 1999 had become infected in the Ivory Coast, in spite of the fact that the Ivory Coast had not officially reported any cases there, and also that the one in the Netherlands in January 2000 originated in Surinam, although again, Surinam had not reported any indigenous cases. Again, from the public health point of view, there is value in knowing where transmission is currently occurring.

The two systems also complement each other because the criteria they use are not the same. WHO reports the three currently notifiable diseases under the IHR - cholera, plague, and yellow fever - plus a number of other outbreaks in humans of interest, including zoonoses. ProMED-mail's stated mission is to report outbreaks of emerging or re-emerging infectious diseases, including the three IHR diseases, acute toxic episodes, and new evidence of resistance to drugs or pesticides - and it does that for human, animal (livestock, domestic, wildlife, and captive), and major crop plant diseases. So, for example, a malaria outbreak is in general only reported by ProMEDmail when it is a case of a new locality record for falciparum malaria or of anti-malarial drug or vector insecticide resistance.

\section{User-friendliness}

E-mail is the key to user-friendliness in global surveillance. Underdeveloped countries and remote locations are increasingly getting email service, but often without full Internet access, so they can send and receive messages but not visit websites - or even if they can, downloading is so slow and connect time so ex-
Table 4

Outbreaks reported by ProMED-mail and CNN, 1999

\begin{tabular}{llll}
\hline Disease & Location & ProMED-mail & CNN* \\
\hline Ebola & Dem. Rep. Congo & 30 April & 3 May \\
Ebola (suspected) & Germany & 4 August & 5 August \\
Dengue & USA (Texas) & 18 August & 28 October \\
Encephalitis & USA (New York) & 5 September & 7 September \\
$\begin{array}{l}\text { E. coli } \\
\text { Salmonella } \\
\text { (dog chews) }\end{array}$ & USA (New York) & 6 September & 6 September \\
\hline
\end{tabular}

* Cable Network News Television

** First reported as St. Louis encephalitis, later discovered

to be due to West Nile virus.

$\star \star \star$ Dried pig ears or leather twists sold for dogs to chew on.

pensive that the web is effectively barred to them. Here e-mail comes into its own as the medium for real-time reporting of outbreaks.

ProMED-mail outbreak reports are delivered to the subscriber's e-mail box without the subscriber having to log on to the web. Both WHO's and ProMED-mail's e-mail lists and websites are free to the public, but the WHO OVL and GPHIN are restricted.

Another user-friendly feature is availability in multiple languages. WHO surveillance reports are available only in English and French. Eurosurveillance Weekly on the Internet is in English, their Monthly in 5 European languages. ProMED-mail is in English, but has a fledgling list in Spanish and Portuguese, and some items are available in Chinese and all, beginning in 1999, as abstracts in Japanese, through ProMED-mail's website.

\section{Conclusions}

This survey shows that recently WHO has greatly improved its speed and usefulness of reporting by creative use of the Internet, by its access to GPHIN, by starting the OVL, and by beginning to report the names of countries from which imported cases in travelers originated, at least for yellow fever. But it is still severely constrained by the slowness of countries in reporting. WHO also now publicly recognizes the value of contributions by NGOs and the media.

ProMED-mail complements WHO's global surveillance system by rapidly disseminating media and subscriber reports of new outbreaks, giving early warning of epidemics which can be further investigated by WHO and the countries concerned. 
Regions and individual countries could benefit from adopting the ProMED-mail model, with its advantages of computers and volunteers provided at no cost. All an outbreak reporting network needs to begin with is a computer (server), free e-mail listserv software such as Majordomo, part of the time of a (computer) postmaster, and a qualified moderator (infectious disease or public health specialist). The network of computers and correspondents

\section{Acknowledgments}

ProMED-mail gratefully acknowledges grants from The Rockefeller Foundation and the Dodge Foundation, and donations from John Marr, John Baldwin, ARCO (Atlantic Richfield Corp.), Pfizer Inc., a number of other corporations, and a very generous anonymous donor. ProMED-mail is also extremely grateful to Nobel Laureate Dr. Joshua Lederberg for his unflagging backing of its mission. The author gratefully acknowledges the support of the New York State Department of Health's Wadsworth Center and the National Research Council of Brazil (CNPq). is provided free by the subscribers, who receive a very useful free service in return.

The system should be based in a university or NGO that is not subject to government constraints on information flow, but must be moderated by health professionals to maintain credibility. Particularly for countries with few government resources, tapping community resources in this way could be very cost-effective, as well as beneficial.

\section{References}

MITCHELL, P., 1997. ProMED-mail: Outbreak intelligence or rash reporting? Lancet, 350:1610.

WHO (World Health Organization), 2000a. Disease Surveillance. January <http://www.who.int/emc/ surveill/index.html>.

WHO (World Health Organization), 2000b. An integrated approach to communicable disease surveillance. Weekly Epidemiological Record, 75:1-8. January <http://www.who.int/wer/pdf/2000/wer 7501.pdf $>$.

WOODALL, J., 1997. Stalking the next epidemic: ProMED tracks emerging diseases. Public Health Report, 112:78-82. 